\title{
OPTIMIZATION OF PROCESS PARAMETERS FOR DRILLING FRP AND ANALYZING CRACKS IN DRILLED LAMINATES
}

\author{
SIVAKUMAR. N. $S^{1} \&$ A. S. BRWA ${ }^{2}$ \\ ${ }^{I}$ Department of Mechatronics Engineering, Tishk International University, Erbil, Iraq \\ ${ }^{2}$ Department of Civil Engineering, Tishk International University, Erbil, Iraq
}

\begin{abstract}
In recent years, “Glass Fiber Reinforced Polymer" (GFRP) composites have been used rapidly as an alternative for conventional materials as more superior to strength to weight ratio and other mechanical behaviors. In this scenario, it is very important to study about drilling of holes perfectly with minimum delamination and cracks by considering the various machining parameters. Applying mathematical strategies is needed to completely analyze the machining process. This task intends to make experimentally analyze the machining properties for drilling of GFRP.
\end{abstract}

KEYWORDS: GFRP, De-Lamination, Rate of Feed, Cutting Speed, Drill Dia, ANOVA Technique \& Taguchi Approach

Received: Feb 14, 2019; Accepted: Mar 04, 2019; Published: Oct 01, 2019; Paper Id.: IJMPERDOCT2019100

\section{INTRODUCTION}

Fiber-Reinforced-Polymer (FRP) composite products are rapidly increasing the usage in various field of science and engineering such as medical, aeronautical, automobile, etc as well as consequently, the demand for exact machining of composites has actually risen tremendously. In order to enhance the accuracy, calculation of thrust force as well as torque of drilled hole by using experimental analysis and theoretical calculation also identify the minimum delamination throughout the drilling surface area. The process parameter criteria of quality and as well as machining features are examined under differing cutting speed (700rpm, 1170rpm, and 1900rpm), feed rate (10mm/min, $20 \mathrm{~mm} / \mathrm{min}$ and $35 \mathrm{~mm} / \mathrm{min})$ and drill size $(6 \mathrm{~mm}, 8 \mathrm{~mm}$ and $10 \mathrm{~mm})$. The trails are carried out experimentally by using $\mathrm{L}_{9}$ orthogonal array and as well as other statistical methods like ANOVA (analysis of variance) techniques are used to examine the impacts in performance qualities in the drilling of FRP composites using High Speed Steel (HSS) twist type drill bits. The important parameter in the drilling operation that influence the performance can be determined that will certainly be of commercial significance regards to applications. The Taguchi optimization approach is used for the verification of optimal values of drilling parameters are executed in order to show the performance.

\section{LITERATURE REVIEW}

Lakshmi Narayanan T et al. [4] reported a research on GFRP composites. The approach deals with delamination, thrust force, tool wear were determined. The cutting tool wear was measured using cutting tool weight difference weight method. The delamination was measured using tool makers microscope Device.

Kilickap E et al. [5] examined on the impact of the process parameters like rate of feed, speed of cutting and also tool geometry, into delamination when drilling operation of GFRP composites. The conclusion revealed that specifically the rate of feed and speed of cutting was one of the most significant elements on the delamination. 
Kishore R A et al. [6] executed a research on the impact of the speed of cutting, rate of feed and also the drill bit point angle on the residual tensile strength of the drilled GFRP composites utilize the Taguchi approach and also recommend the optimum for parameters for residual tensile strength.

MustafaKurt et al. [7] in this paper cutting parameters was optimized in terms of Surface Finish and accuracy of diameter in drilling operation (without coolant) by using Taguchi techniques. To obtain these qualities, an investigation was conducted using aluminum alloy metal (Al 2024 grade).

The whole qualities were assessed under differing cutting speeds, feed rate, drill depth and various HSS twist drill bits with a 118 degree angle of point. Taguchi technique, ANOVA, Signal/Noise Ratio (SNR) and also regression equation were utilized to discover the optimum degrees as well as to examine the impact of the drilling process parameters on values of surface finishing and values of whole dia accuracy.

ShyhaI S et al. [8] used an orthogonal range of array of $\mathrm{L}_{12}$ selected for Taguchi technique and ANOVA method were used to review the results of drill geometry as well as drilling conditions on hole quality and tool life.

Karin Kandananond et al. [9] achieved the most effective cutting parameters for decreasing the roughness of surface in turning operation of "AISI 12L14" Grade steel. The array of orthogonal $\mathrm{L}_{18}$ with five trails, the ratio of S/N and the ANOVA were employed to identify optimum process parameters for acquiring the expected quality of surface finish.

GaitondeV N et al. [10] established the Taguchi approach for the reduction of delamination at the entrance as well as at the end of the hole in drilling of medium density fibre board. The main concept has actually been utilized for the multiperformance oriented optimization of characteristics by use of Taguchi method.

Tsao C C et al. [11] in this experimental research, study on the analysis of thrust force and surface finish in drilling of composite by utilizing candle stick type drill bit. The Taguchi based approach and also the artificial neural networks were used.

GaitondeV N et al. [12] used Taguchi based optimization approach for reduction of burr thick as well as burr length affected by machine parameters and also the geometry of the drill. In this investigation, suitable values of speed of cutting, feed rate, drill bit point angle and also angle of clearance are figured out for chosen the values of drill dia to decrease burr thick as well as burr length while drilling operation of AISI 316L metal by use of Taguchi method.

Tsao C C et al. [13] executed a research on Taguchi's optimizing technique. In this research, orthogonal of $\mathrm{L}_{18}$ array was chosen to recognize the drilling results with optimized parameters such as ratio of diameters (Major and Minor), feed and also cutting velocity on delamination for different size of drill bits.

Han-Ming Chow et al. [14] discovered exactly, the various process criteria like drill geometric shape, angle of friction, area of frictional contact ratio, feed and spindle rpm would certainly influence the reaction specification for AISI 304 grade metal utilizing Taguchi’s approach.

Basavarajappa S et al. [15] examined the impact of parameter on drilling behavior of hybrid MMC composites. Taguchi's method and also ANOVA were utilized to predict the drilling characters of composites. The investigation were executed to consider the impact of drilling velocity and feed on feed force, surface roughness and burr size utilizing solid carbide multifaceted drill of $5 \mathrm{~mm}$ size. 
Pawade R S et al. [16] examined the nature of delamination upon the machined area and the machining affected zone (MAZ) thickness. The residual strength and micro hardness tests and increased work piece hardness (due to machining) in the machined sub surface were utilized as standards to acquire the optimal parameters that offer machined surface areas with good quality by use of Taguchi technique.

Nalbant M et al. [17] utilized Taguchi's techniques to discover the ideal parameter criteria (radius of insert, feed, and depths of cutting) for surface finish in plain turning. The Signal-Noise ratio and ANOVA were utilized to research the operation characters of turning process of "AISI 1030" steel work piece utilizing tool coated with TiN.

Basavarajappa $S$ et al. [18] utilized a strategy of investigation based upon Taguchi's approach to get the information in a regulated means. An array of orthogonal and ANOVA were utilized to explore the impact of tool wear specifications were normal load, velocity and distance due dry friction of the work piece.

Tang S H et al. [19] in this research a molded plate generated for a slim plate making from plastic product. The item was utilized for the testing of war page on the efficient factors of the war page issue by using the application of Taguchi approach.

Tsao C C et al. [20] experimental research was making use of Taguchi technique where the thrust force of core drill with differing parameters in drilling CFRP experiments were explored.

Mohan N S et al. [21] presented the results criteria like rpm, rate of feed, as well as drill dimension and also work piece dimension in a CNC machining operation. An experimental trail was carried out by making use of "TRIAC" CNC Vertical Machining Centre facility to correlate the cutting factor and also material parameters on the thrust as well as torque. The determined outcomes were gathered and also assessed with the assistance popular software (MINITAB14). An orthogonal array, $\mathrm{S} / \mathrm{N}$ ratio were utilized to assess the impact of parameters on cutting thrust as well as torque throughout the drilling.

Tsao C C et al. [22] this research was mainly focused on the analysis of delamination by use of twist type drills, candle-stick type drills and also saw type drills. This strategy was based upon Taguchi technique as well as ANOVA method. The purpose was to develop a relationship in feed, rate of cutting rpm and also drill size with the generated delamination in a Carbon Fiber Reinforced Plastics laminate. The relation was acquired by multivariable regression then compared to the trail outcomes.

Paulo Davim et al. [23] did a research on parameters speed as well as feed under certain cutting force, the thrust force in GFRP. The main purpose was to develop a relationship of speed and feed with the details reducing stress, drive pressure, damages factor and also roughness of surface in a GFRP composites.

Paulo Davim et al. [24] examined the impact of reducing specifications spindle speed, feed and also machining time on drilling metal-matrix composites. The aim of this research was to develop relation in the speed, feed and the operation time with the tool wear rate, the cutting force and the roughness in whole surfaces.

Tsann et al. [25] described and optimized the operating parameters (cutting velocity, feed and depth) by making use of the Taguchi approach. An orthogonal-array, $\mathrm{S} / \mathrm{N}$ ratio, and the ANOVA were utilized to examine the characters of face milling process.

Thus from literature study, it is noted that study tasks have actually been described in the area of drilling GFRP, very rarely few couple of researches only reported the effect of drill dia in drilling of GFRP composites. Besides the design 
for manufacturing and assembly, the whole size key is important in applications aspect. In commercial applications a number of procedure designers have tendency to utilize smaller sized holes for setting up of laminate panels for the extremely functions of simple procedure security control and also the accomplishment of exact setting up of panels. For this reason, in this job, drill size is consisted of together with various other typical criteria like velocity and as well as feed. This research was mainly focused to examine the impacts of cutting velocity, rate of feed and drill dia on delamination when drilling GFRP composites laminate.

\section{TESTING OF SPECIMEN}

\section{Preparation of Test Speciman}

The selected test specimen for the experiment is fiber reinforced plastics (FRP). The FRP composite specimen is made up through had laid up manufacturing technique.

\section{Tensile Test}

- Size of test Specimen (in $\mathrm{mm}$ ) for tensile testing is $185 \mathrm{~mm} \times 50 \mathrm{~mm} \times 2 \mathrm{~mm}$.

- The work is fixed at both ends by using hooks in the tensile testing machine.

- The specimen was fractured at the load of $400 \mathrm{~kg}$.

- Yield strength of specimen is 54.5 Mpa.

The Comparison of Tensile Test of specimen by using universal testing machine is mentioned in table 1 .

Table 1: Comparison of Tensile Test

\begin{tabular}{|c|l|c|}
\hline S No & \multicolumn{1}{|c|}{ Composition } & Yield Strength in Mpa \\
\hline 1 & GFRP & 52 \\
\hline 2 & GFRP(60\%Fiber40\%Resin) & 54.4 \\
\hline
\end{tabular}

\section{Rockwell Hardness Test}

The hardness is tested by using Rockwell hardness testing machine. By applying load and afterwards determine the depth of penetration. The indenter might either be a steel round of some defined size or a round diamond-tipped cone of $120^{\circ}$ angle and also $0.4 \mathrm{~mm}$ tip dia, known as a brale. Initially $10 \mathrm{~kg}$ load is applied, to avoid irregularity of surface and which makes a light penetration for locating of indenter properly. After that, the dial is reset to zero and then significant (major) load is applied on the specimen. Upon releasing of the significant (major) load, the deep of depth is measured while the small load remains same. Then hardness number may be read straight away from the main scale which is fixed in the machine. The indenter and also the examination plots were utilized to establish the firmness range that is utilized (A B C etc).

For soften materials like copper alloy, steel alloys, and aluminium alloy a 1/16 inches ball shaped steel intender is using with load of $100 \mathrm{~kg}$ and the hardness number is measured in the scale B. For hard materials like cast iron and as well as other steel alloy, an angle of $120^{\circ}$ diamond- cone is used with maximum load of $150 \mathrm{~kg}$ and the hardness number is measured in the scale C. There are many Rockwell scale apart from the B and C scale. The exactly measured Rockwell hardness value will show in respective scale followed by a number and letter. For example if "50 HRB" means, the specimen has a hardness value of 50 on the B scale in the harness testing machine. 
- $\quad$ Specimen size in $\mathrm{mm}$ is $95 \times 90$.

- Total Number of Trials is 10 times.

- Value of Harness number is 48HRB.

\section{Elastic Properties of the Material}

The following elastic properties are found for GFRP composites.

Table 2: Elastic Property of Material

\begin{tabular}{|l|c|c|}
\hline $\begin{array}{l}\text { Modulus of elasticity along the } \\
\text { fiber direction }\end{array}$ & $\mathrm{E}_{11}$ & $132 \times 10^{6} \mathrm{M}$ pa \\
\hline $\begin{array}{l}\text { Modulus of elasticity along the } \\
\text { transverse direction of fiber }\end{array}$ & $\mathrm{E}_{22}$ & $11 \times 10^{6} \mathrm{Mpa}$ \\
\hline Shear Modulus & $\mathrm{G}_{12}$ & 5.5 \\
\hline Poisson's Ratio & $\mu_{11}$ & 0.33 \\
\hline thickness of the ply & $\mathrm{t}$ & $0.15 \mathrm{~m}$ \\
\hline
\end{tabular}

\section{DRILLING OPERATIONS}

Using arix vmc $100 \mathrm{cnc}$ machines, the drilling operation is carried out. The HSS twist drill bit of different diameter $6 \mathrm{~mm}$, $8 \mathrm{~mm}$ and $10 \mathrm{~mm}$ are used. The GFRP laminate of thickness $10 \mathrm{~mm}$ with 24 layers made by hand layup process and it had a $55 \%$ cured fiber volume ratio. The dimension of specimen in $\mathrm{mm}$ is $300 \times 100 \times 10$.

\section{EXPERIMENTAL TRIALS}

In the experimental set up a series of trials were carried out and the specimen utilized for the experiment is GFRP composite. The thrust force and torque were measured in each trail based on desired values of process parameters of Cutting speed, Feed rate and Drill diameter.

- The trail specimen is made up of glass fibers with polyester resin.

- Thickness of material is $7.5 \mathrm{~mm}$.

- Total number of layers is 5 .

- The surface of the Material is coated with wax.

Table 3: Process Parameters of Drilling

\begin{tabular}{|c|c|c|c|}
\hline Cutting speed(rpm) & 700 & 1170 & 1900 \\
\hline Feed rate $(\mathrm{mm} / \mathrm{min})$ & 10 & 20 & 35 \\
\hline Drill diameter(mm) & 6 & 8 & 10 \\
\hline
\end{tabular}

Table 4: Experimental Trials

\begin{tabular}{|c|c|c|c|c|c|}
\hline Trial & $\begin{array}{c}\text { Drill Bit Size } \\
(\mathbf{m m})\end{array}$ & $\begin{array}{c}\text { Cutting Speed } \\
(\mathbf{R P M})\end{array}$ & $\begin{array}{c}\text { Feed Rate } \\
(\mathbf{m m} / \mathbf{m i n})\end{array}$ & Thrust Force & Torque \\
\hline 1 & 6 & 700 & 10 & 8.5 & 6 \\
\hline 2 & 6 & 1170 & 20 & 9.4 & 5.7 \\
\hline 3 & 6 & 1900 & 35 & 10.2 & 6.2 \\
\hline 4 & 8 & 700 & 10 & 11.5 & 7.2 \\
\hline 5 & 8 & 1170 & 20 & 12.2 & 7.5 \\
\hline 6 & 8 & 1900 & 35 & 14 & 7.8 \\
\hline 7 & 10 & 700 & 10 & 16.5 & 8.2 \\
\hline
\end{tabular}




\begin{tabular}{|c|c|c|c|c|c|}
\hline \multicolumn{7}{|c|}{ Table 4: Contd., } \\
\hline 8 & 10 & 1170 & 20 & 17.2 & 8.3 \\
\hline 9 & 10 & 1900 & 35 & 19 & 8.7 \\
\hline
\end{tabular}

\section{RESULTS AND DISCUSSIONS}

\section{Analysis of Variance (ANOVA)}

The experimental variables are analyzed by using ANOVA method as follows. The mathematical equation is (Ratio of Signal-Noise)

$$
S / N=-10 \log \frac{1}{n} \sum_{t=1}^{n} y_{i}^{2},
$$

where

$$
\begin{aligned}
& \mathrm{y}_{\mathrm{i}}-\text { is the performance characteristics (output) } \\
& \mathrm{n}-\text { is the total number of experimental trails }
\end{aligned}
$$

\section{Data Analysis}

The main objective of this analysis is to decrease the thrust force and torque in order to use the ANOVA and to investigate the optimal parameters based upon the Taguchi technique. The drilling operation performance (ANOVA) can be computed for each experiment of the L9 by utilizing the observed values of the drill size, speed and feed from table 5 tables 7 and 9 show the ANOVA test results for thrust force and torque, respectively. The optimal operating conditions of drilling parameters (ANOVA-optimum condition) for each of the observed values are shown in Tables 10 and 11.

Table 5: Thrust Force and Torque using ANOVA

\begin{tabular}{|c|c|c|c|c|c|c|c|}
\hline Test & $\begin{array}{c}\text { Drill dia } \\
(\mathbf{m m})\end{array}$ & $\begin{array}{c}\text { Speed } \\
(\mathbf{r p m})\end{array}$ & $\begin{array}{c}\text { Feed } \\
(\mathbf{m m} / \mathbf{m i n})\end{array}$ & Thrust force(kg) & S/N ratio & torque & S/N ratio \\
\hline 1 & 6 & 700 & 10 & 8.5 & 18.58 & 6 & 15.56 \\
\hline 2 & 6 & 1170 & 20 & 9.4 & 19.46 & 5.7 & 15.12 \\
\hline 3 & 6 & 1900 & 35 & 10.2 & 20.17 & 6.2 & 15.84 \\
\hline 4 & 8 & 700 & 20 & 11.5 & 21.21 & 7.2 & 17.14 \\
\hline 5 & 8 & 1170 & 35 & 12.2 & 21.72 & 7.5 & 17.50 \\
\hline 6 & 8 & 1900 & 10 & 14 & 22.92 & 7.8 & 17.84 \\
\hline 7 & 10 & 700 & 35 & 16.5 & 24.34 & 8.2 & 18.27 \\
\hline 8 & 10 & 1170 & 10 & 17.2 & 24.71 & 8.3 & 18.38 \\
\hline 9 & 10 & 1900 & 20 & 19 & 25.57 & 8.7 & 18.79 \\
\hline
\end{tabular}

\section{Theoretical Calculation of Thrust Force and Torque}

Torque $\mathrm{M}=\mathrm{H}_{\mathrm{b}} \mathrm{D}^{2} \mathrm{~F} / 8$

Thrust force $=\mathrm{T} 1+\mathrm{T} 2$

Where,
$\mathrm{H}_{\mathrm{b}}=$ Hardness of the Specimen,
$\mathrm{D}=$ Diameter of the holes $\mathrm{mm}$, 
$\mathrm{F}=$ Feed $\mathrm{mm} / \mathrm{rev}$,

$\mathrm{W}=\mathrm{Web}$ thickness

$\mathrm{T}_{1}=(1.7$ to 3.5$) \mathrm{M} / \mathrm{D}$

$\mathrm{T}_{2}=(0.1$ to 0.2$) \Pi / 4 \mathrm{~W}^{2} \mathrm{H}_{\mathrm{b}}$

$\mathrm{W}=0.14 \mathrm{D}$

Thrust force $=\mathrm{T}_{1}+\mathrm{T}_{2}$

\section{Model Calculation}

$\mathrm{H}_{\mathrm{b}}=48 \mathrm{HRB}$

$\mathrm{D}=6 \mathrm{~mm}$

$\mathrm{F}=10 \mathrm{~mm} / \mathrm{min}=10 / 700=0.014 \mathrm{~mm} / \mathrm{rev}$

Torque $\mathrm{M}=\mathrm{H}_{\mathrm{b}} \mathrm{D}^{2} \mathrm{~F} / 8$

$\mathrm{M}=48 * 6^{2 *} * 014 / 8$

Torque $\mathrm{M}=3.024 \mathrm{Kgm}$

$\mathrm{T}_{1}=(1.7$ to 3.5$) \mathrm{M} / \mathrm{D}$

$\mathrm{T}_{1}=3.5 * 3.024 / 6$

$\mathrm{T}_{1}=2.66$

$\mathrm{T}_{2}=(0.1$ to 0.2$) \Pi / 4 \mathrm{~W}^{2} \mathrm{H}_{\mathrm{b}}$

$\mathrm{W}=0.14 * 6=0.84$

$\mathrm{T}_{2}=0.2 * \Pi / 4 * 0.842 * 48$

$\mathrm{T}_{2}=5.32$

Thrust force $\mathrm{T}=\mathrm{T}_{1}+\mathrm{T}_{2}$

$\mathrm{T}=2.66+5.32$

Thrust force $\mathrm{T}=7.084 \mathrm{Kgf}$.

Table 6: Theoretical Thrust Force and Torque

\begin{tabular}{|c|c|c|c|c|c|}
\hline \multirow{2}{*}{ S. No } & \multirow{2}{*}{$\begin{array}{c}\text { Drill Diameter } \\
(\mathbf{m m})\end{array}$} & \multirow{2}{*}{$\begin{array}{c}\text { Speed } \\
(\mathbf{r p m})\end{array}$} & $\begin{array}{c}\text { Feed } \\
(\mathbf{m m} / \mathbf{m i n})\end{array}$ & \multicolumn{2}{|c|}{ Theoretical Values } \\
\cline { 5 - 6 } & 6 & 700 & 10 & 7.08 & 3.02 \\
\hline 1 & 6 & 1170 & 20 & 7.46 & 3.69 \\
\hline 2 & 6 & 1900 & 35 & 7.90 & 4.44 \\
\hline 3 & 8 & 700 & 20 & 7.69 & 5.30 \\
\hline 4 & 8 & 1170 & 35 & 12.34 & 6.56 \\
\hline 5 & 8 & 1900 & 10 & 12.54 & 7.07 \\
\hline 6 & 10 & 700 & 35 & 17.77 & 8.57 \\
\hline 7 & 10 & 1170 & 10 & 18.34 & 10.2 \\
\hline 8 & 10 & 1900 & 20 & 18.27 & 11.0 \\
\hline 9 & & & & & \\
\hline
\end{tabular}


Table 7: Response Table for Signal to Noise Ratios Smaller is Better

\begin{tabular}{|c|c|c|c|}
\hline Level & $\begin{array}{c}\text { Drill } \\
\text { Diameter }\end{array}$ & Cutting- Speed & Feed Rate \\
\hline 1 & 19.41 & 21.38 & 22.07 \\
\hline 2 & 21.95 & 21.97 & 22.08 \\
\hline 3 & 24.88 & 22.89 & 22.08 \\
\hline
\end{tabular}

Table 8: Responds Table for Means

\begin{tabular}{|c|c|c|c|}
\hline Level & $\begin{array}{c}\text { Drill } \\
\text { Diameter }\end{array}$ & Cutting Speed & Feed rate \\
\hline 1 & 9.367 & 12.167 & 13.233 \\
\hline 2 & 12.567 & 12.933 & 13.300 \\
\hline 3 & 17.567 & 14.400 & 12.967 \\
\hline
\end{tabular}

Table 9: Taguchi Analysis: Torque Verses Drill Dia, Speed and Feed

\begin{tabular}{|c|c|c|c|}
\hline Level & Drill Diameter & Cutting Speed & Feed Rate \\
\hline 1 & 15.51 & 17.01 & 17.26 \\
\hline 2 & 17.50 & 17.00 & 17.02 \\
\hline 3 & 18.48 & 17.49 & 17.29 \\
\hline
\end{tabular}

Table 10: Responds Table for Means

\begin{tabular}{|c|c|c|c|}
\hline Level & $\begin{array}{c}\text { Drill } \\
\text { Diameter }\end{array}$ & Cutting Speed & Feed Rate \\
\hline 1 & 5.967 & 7.133 & 7.367 \\
\hline 2 & 7.500 & 7.167 & 7.200 \\
\hline 3 & 8.400 & 7.567 & 7.300 \\
\hline
\end{tabular}

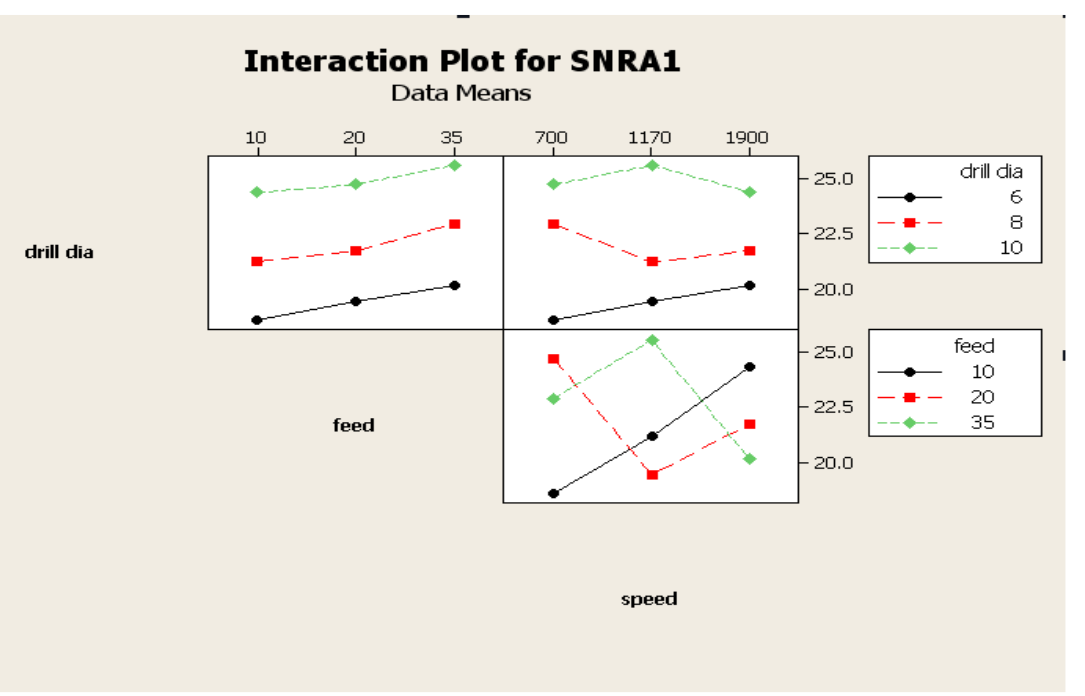

Figure 1: Plot for Thrust Force Interaction. 


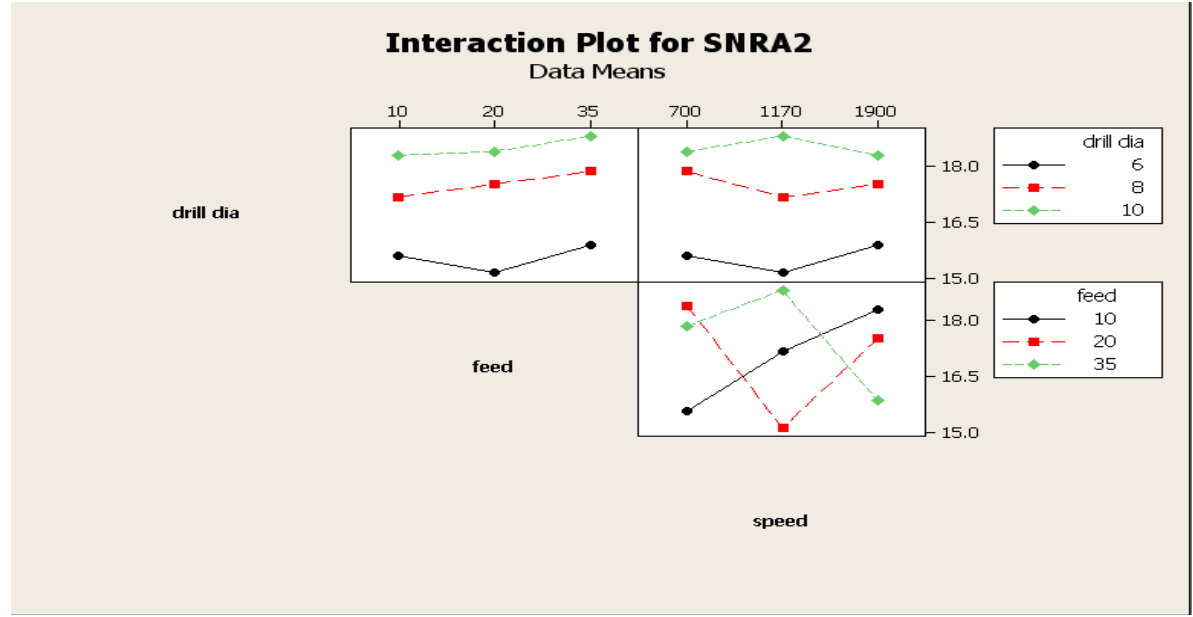

Figure 2: Plot for Thrust Force Interaction

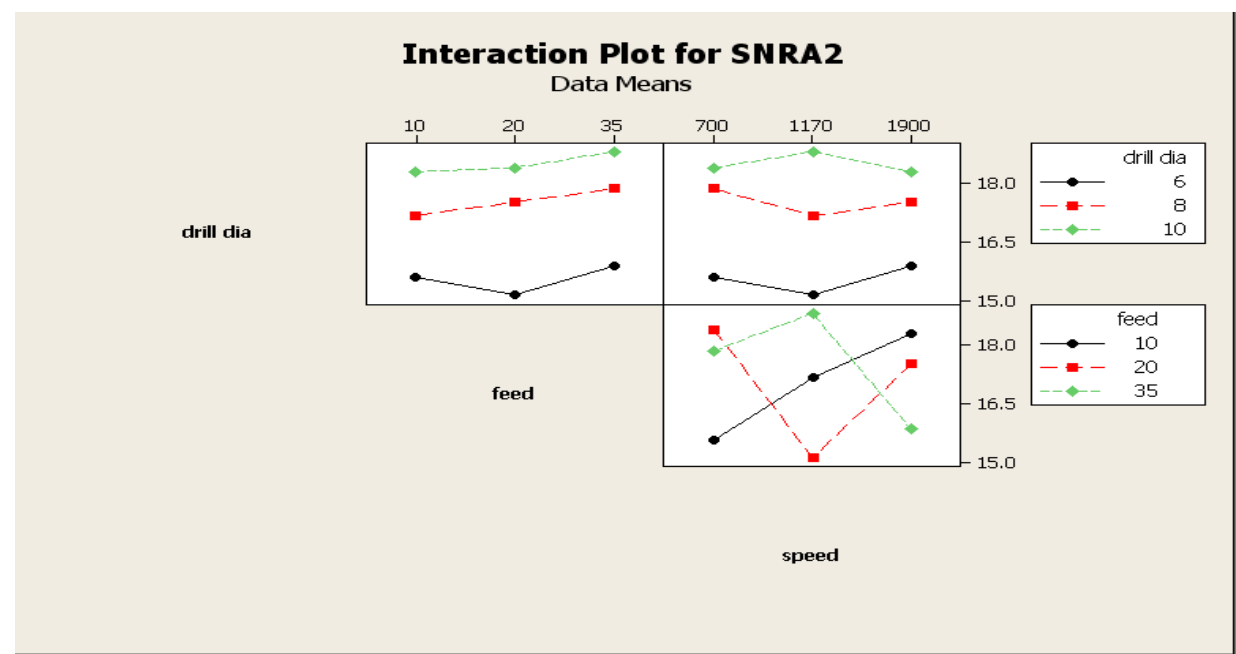

Figure 3: Plot for Torque Interaction

\begin{tabular}{|c|c|c|c|}
\hline \multicolumn{4}{|c|}{ Table 11: Optimum Working Parameters from Theoretical Calculation } \\
\hline $\begin{array}{c}\text { Working } \\
\text { Parameters }\end{array}$ & $\begin{array}{c}\text { Drill Diameter } \\
(\mathbf{m m})\end{array}$ & $\begin{array}{c}\text { Cutting Speed } \\
(\mathbf{r p m})\end{array}$ & $\begin{array}{c}\text { Feed Rate } \\
(\mathbf{m m} / \mathbf{m i n})\end{array}$ \\
\hline Thrust force & 6 & 700 & 10 \\
\hline Torque & 6 & 700 & 10 \\
\hline
\end{tabular}

Table 12: Optimum Working Parameters from the Graph

\begin{tabular}{|c|c|c|c|}
\hline $\begin{array}{c}\text { Working } \\
\text { Parameters }\end{array}$ & $\begin{array}{c}\text { Drill Diameter } \\
(\mathbf{m m})\end{array}$ & $\begin{array}{c}\text { Cutting Speed } \\
(\text { RPM })\end{array}$ & $\begin{array}{c}\text { Feed Rate } \\
(\mathbf{m m} / \mathbf{m i n})\end{array}$ \\
\hline Thrust force & 6 & 700 & 10 \\
\hline Torque & 6 & 1170 & 20 \\
\hline
\end{tabular}

S/N Ratio Plots obtained by using MINITAB 14

The interaction plot shown in Figure 2 represents the interaction of process parameters on thrust force with respect to drill dia \& cutting speed, drill dia \& feed rate and also cutting speed \& feed rate. The interaction plot shown in Figure 3 represents the interaction of process parameters on torque with respect to drill dia \& cutting speed, drill dia $\&$ feed rate and also cutting speed $\&$ feed rate. 


\section{CONCLUSIONS}

Various kinds of GFRP composites and its performance, characteristics and machining capabilities were gathered and studied. The specimen were performed and measure the yield-strength and hardness number by using universal testing machine and Rockwell hardness testing machine. The comparisons were made with traditional GFRP with measured values of specimen. From the table listed above mentioned that the yield-strength and hardness of the material is higher than the traditional GFRP.

The major drilling defects caused due to thrust force and torque. As mentioned in the tables 10 and 11, it clears that at lower cutting speed, feed rate and small size drill bit causes minimum thrust force and torque. Therefore delamination while drilling operations are minimized when drilling at minimum input parameters.

\section{REFERENCES}

1. NaRoss P J (1988), “Taguchi Techniques for Quality Engineering”, McGraw-Hill, New York.

2. Graham T Smith (2008), “Cutting Tool Technology”, Springer-Verlag London Limited, London, pp 1-8, 87-117.

3. Thomas Childs, Katsuhiro Maekawa Toshiyuki Obikawa and Yasuo Yamane (2000), "Metal Machining Theory and Applications," Great Britain, London, pp 30-34, 265-283.

4. Lakshmi narayanan T, Madhavan S and Ankur Sinha (2010), "Investigation of Thrust, Torque and Drilling of Glass Fabric/Polypropylene Matrix Composite”, Proceedings of International Conference on Recent Advances in Mechanical and Electrical Technology.

5. Kilickap E (2010), "Optimization of Cutting Parameters on Delamination Based on Taguchi Method during Drilling of GFRP Composite”, Expert Systems with Applications, Volume. 37, 6116-6122.

6. Krishna M. M., Rao N. D. P., Prasad B. A. \& Murthy P. V. K. (2014). "Investigations on performance parameters with medium grade low heat rejection combustion chamber with rice brawn oil biodiesel”. International Journal of Applied Engineering Research and Development,4 (1), 29-46.

7. Kishore R A, Tiwari R, Dvivedi A and Singh I (2009), “Taguchi Analysis of The Residual Tensile Strength after Drilling in Glass Fiber Reinforced Epoxy Composites”, Materials and Design, Volume. 30, 2186-2190.

8. Mustafa Kurt, Eyup Bagci and Yusuf Kaynak (2009), “Application of Taguchi Methods in the Optimization of Cutting Parameters for Surface Finish and Hole Diameter Accuracy in Dry Drilling Processes”, International Journal of Advanced Manufacturing Technology, Volume. 40, 458-469.

9. Shyha I S, Aspinwall D K, Soo S L and Bradley S (2009), "Drill Geometry and Operating Effects when Cutting Small Diameter Holes in CFRP”, International Journal of Machine Tools and Manufacture, Volume. 49, 1008-1014.

10. Karin Kandananond (2009), “Characterization of FDB Sleeve Surface Roughness Using the Taguchi Approach”, European Journal of Scientific Research, Volume. 33, 330-337.

11. Krishnan K., \& Thangamani V. Quantitative Apprisal of Areal Parameters in Morphometric Study of Malattar River Basin.

12. Gaitonde V N, Karnik S R, Paulo and Davim J (2008), "Taguchi Multiple-Performance Characteristics Optimization in Drilling of Medium Density Fibreboard (MDF) to Minimize Delamination using Utility Concept”, Journal of Materials Processing Technology, Volume 196, 73-78.

13. Tsao C C and Hocheng H (2008), "Evaluation of Thrust Force and Surface Roughness in Drilling Composite Material using Taguchi Analysis and Neural Network”. Journal of Materials Processing Technology, Volume 203, 342-348. 
14. Gaitonde V N, Karnik S R, Achyutha B T and Siddeswarappa B (2008), "Taguchi Optimization in Drilling of AISI $316 L$ Stainless Steel to Minimize Burr Size using Multi-Performance Objective Based on Membership Function”, Journal of Materials Processing Technology, Volume 202, 374-379.

15. Tsao C C (2008), "Investigation into the Effects of Drilling Parameters on Delamination by Various Step-Core Drills". Journal of Materials Processing Technology, Volume 206, 405-411

16. Han-Ming Chow, Shin-Min Lee and Lieh-Dai Yang (2008), "Machining Characteristic Study of Friction Drilling on AISI 304 Stainless Steel”, Journal of Materials Processing Technology, Volume 207, 180-186.

17. Basavarajappa S, Chandramohan G and Paulo Davim J (2008), "Machining Some Studies on Drilling of Hybrid Metal Matrix Composites Based on Taguchi Techniques”, Journal of Materials Processing Technology, Volume 196, 332-338.

18. Euloge F. M. O., Simplice G. L. \& Cloud H. L. Action of the Combination of Alternaria Alternata and Neochetina Eichhorniae on Growth Parameters of the Water Hyacinth in a Controlled Environment.

19. Pawade R S, Suhas S Joshi and Brahmankar P K (2008), "Effect of Machining Parameters and Cutting Edge Geometry on Surface Integrity of High-Speed Turned Inconel 718”, International Journal of Machine Tools and Manufacture, Volume. 48, $15-28$.

20. Nalbant M, Gokkaya H and Sur G (2007), "Application of Taguchi Method in the Optimization of Cutting Parameters for Surface Roughness in Turning”, Materials and Design, Volume 28, 1379-1385.

21. Basavarajappa S Chandramohan G and Paulo Davim J (2007), “Application of Taguchi Techniques to Study Dry Sliding Wear Behaviour of Metal Matrix Composites”, Materials and Design, Volume 28, 1393-1398.

22. Tang S H, Tan Y J, Sapuan S M, Sulaiman S, Ismail N and Samin R (2007), "The Use of Taguchi Method in the Design of Plastic Injection Mould for Reducing warpage”, Journal of Materials Processing Technology, Volume 182, 418-426.

23. Tsao C C and Hocheng H (2007), "Parametric Study on Thrust Force of Core Drill", Journal of Materials Processing Technology, pp 37-40, 192-193.

24. Mohan N S, Ramachandra A and Kulkarni S M (2005), "Influence of Process Parameters on Cutting Torque during Drilling of Glass-Fiber Polyester Reinforced Composites”, Composite Structures, Volume 71, 407-413.

25. Tsao C C and Hocheng H (2004), "Taguchi Analysis of Delamination Associated with Various Drill Bits in Drilling of Composite Material”, International Journal of Machine Tools and Manufacture, Volume 44, 1085-1090.

26. Paulo Davim, Pedro Reis J and Conceicao Antonio C (2004), “Experimental Study of Drilling Glass Fiber Reinforced Plastics (GFRP) Manufactured by Hand Lay-up”, Composites Science and Technology, Volume 64, 289-297.

27. Paulo Davim J (2003), "Study of Drilling Metal-Matrix Composites Based on the Taguchi Techniques", Journal of Material Processing Technology, Volume 132, 250-254.

AL Somahi, A. A., Mousa, S., \& AL Turk, L. I. (2015). Some New Proposed Ridge Parameters for the Logistic Regression Model. International Journal of Research in Applied Natural and Social Sciences (IMPACT: IJRANSS), 3 (1), 67-82. TsannRong Lin, "Experimental design and performance analysis of TiN-coated carbide tool in face milling stainless steel", journal of material processing technology 127 (2002) 1-7. 
